\title{
A REPARTIÇÃO DE COMPETÊNCIAS ENTRE O TRIBUNAL DE JUSTIÇA DAS COMUNIDADES EUROPEIAS E O TRIBUNAL DE PRIMEIRA INST ÂNCIA
}

José de Campos Amorim

\section{INTRODUÇÃOO}

A União Europeia acaba de proceder a uma importante reforma de todo o sistema institucional comunitário, para fazer face ao alargamento e aprofundamento da União, e sobretudo à necessidade de aproximar os cidadãos da justiça comunitária.

O Tratado de Nice tenta promover un conjunto de reformas importantes ao nível do sistema político, legislativo, executivo e jurisdicional comunitário para evitar uma crise política e institucional'. Esses ajustamentos institucionais vão incidir essencialmente sobre a estrutura da Comissão Europeia, o equilíbrio de poderes entre os Estados-membros no Conselho de Ministros, o aumento das áreas de competência do Conselho de Ministros, o reforço das competências do Parlamento Europeu, o alargamento das cooperações reforçadas e a reforma do sistema jurisdicional da União.

Neste último domínio, as principais alterações introduzidas pelo Tratado de Nice consistem na redefinição da arquitectura jurisdicional comunitária e, em particular, na atribuição de novas competências ao Tribunal de Justiça da União Europeia (Tribunal de Justiça) e ao Tribunal de Primeira Instância (TPI), na repartição de competências ente as duas instituições e na criação de câmaras jurisdicionais.

O Tratado de Nice veio assim alterar o sistema jurisdicional em

\footnotetext{
' Miguel Poiares Maduro, O Tratado de Nice e o Futuro da Europa. Parecer solicitado à Faculdade de Direito da Universidade Nova de Lisboa pela Assembleia da Republica, 2001, p. 15.
} 
vários pontos, essencialmente no reconhecimento ao TPl de uma competência geral de primeira instância, tal como resulta da nova redacção do artigo 225." do Tratado das Comunidades Europeias, e na atribuição ao Tribunal de Justiça de uma função de tribunal constitucional.

Esta repartição de competências foi introduzida com o intuito de aliviar o Tribunal de Justiça e de tornar o sistema jurisdicional mais eficaz, tendo em conta as novas exigências comunitárias. Nesse sentido, foi atribuído ao TPI uma competência prejudicial em matétias específicas determinadas pelo Estatuto, foram criadas câmaras jurisdicionais encarregadas de conhecer em primeira instância certas categorias de recursos em matérias cspecificas, e efectuada uma repartiçä́o de competências entre o Tribunal de Justiça co TPI em matéria de recursos directos?.

O novo sistema jurisdicional comunitário prevê a atribuição de novas competências ao Tribunal de Justiça, ao TPI e às câmaras jurisdicionais, tornando o sistema mais complexo e menos cficar, pelo facto, por exemplo, de a repartição de competências entre as diversas instâncias não ter sido claramente delinida no Estatuto do Tribunal de Justiça, correndo-se aqui até o risco de pôr em causa a unidade e coerência do direito comunitário e a prolecção jurisdicional efectiva dos direitos e interesses das pessoas.

Ao primeiro olhar, o sistema agora aprovado parece salisfatório na medida em que procede a uma reforma impottante, mas, à segunda vista, levanta uma série de dúvidas no que diz respeito à repartição de competências entre o Tribunal de Justiça e o TPI. É precisamente esta questão que iremos analisar ao longo deste estudo, apontando algumas das dificuldades suscitadas, nomeadamente nas matérias que foram transferidas da competência do Tribunal de Justiça para a do TPI, e quanto à possibilidade deste último apreciar certas questŏes prejudiciais. Também não deixaremos de apontar algumas soluçóes que consideramos adequadas e possíveis.

No contexto, apresentaremos as alterações introduzidas ao nível da organização judiciária e analisaremos as competências do TPI e do Tribunal de Justiça, as competências das câmaras jurisdicionais, a

"Artigo 225.", n." 1, do Tratado Cb. Ver Fausto de Quadros e Ana Maria Guerra Martins, Contencioso Connutúríto. Almedina, 2002, pp. $104 \mathrm{c}$ segs. 
transferência dos recursos directos, os crilérios de repartição de competências entre o Tribunal de Justiça e o TPl, e o tratamento da questão prejudicial.

\section{A NOVA ORGANIZAÇÃO JUDICIÁRIA COMUNITÁ- RIA}

O Tratado de Nice efectua importantes alteraçōes ao nível da organização judiciária comunitária’. O Tribunal de Justiça, composto por um juiz por Estado-membro, e assistido por oilo advogados-gerais, nomeados de comum acordo pelos Estados-membros por um período de seis anos, desempenha duas funções principais: a de verificar a compatibilidade com o 'Tratado da União Europeia dos actos das instituições europeias e dos Governos, c a de se pronunciar, a pedido de um tribunal nacional, sobre a interpretação ou validade das disposiçóes do direito comunitário.

O Tribunal de Justiça é assistido por um Tribunal de Primeira Instância, instituído em 1989, com competência para "conhecer dos recursos referidos nos artigos $230 .^{\circ}, 232 .^{\circ}, 235 .^{\circ}, 2360^{\circ}$ e $238 .^{\circ}$, à excepção dos atribuídos a uma câmara jurisdicional e dos que o Estatuto reservar para o Tribunal de Justiça", conforme dispöe o artigo 225.", n." 1, do Tratado das Comunidades Europeias (em diante Tratado CE).

O TPI é composto por, pelo menos, um juiz por Estado-membro, sendo o número de juízes a definir pelo Estatuto do Tribunal de Justiça, conforme prevê o artigo $224 .^{\circ}$ do 'Tratado CE. Esta disposição permi-

"Dámaso Ruiz-Jarabo, El Tribural de Justicia y el Tratado de Niza, Gaceta jurídica de la Unión Europeia, Madrid, |11." 212, Marzo-Abril 2001, pp. 4 c segs.

"Joào Motas de Campos é da opiniäo de "o aumento do número de juízes e de advogados-gerais, matéria sobre que o Conselho está habilitado a deliberar, é uma solução que tcun os seus limites e que, não sendo a única, também năo era necessariamente a mais adequada; até porque muitos dos casos submetidos à Justiça Comunitália (especialmente aqueles em que são partes os particulares - pessoas singulares ou colectivas e, designadamente, os funcionátios comunitários) năo têm importância que justifique que deles se ocupe, salvo para os julgar em eventual recurso limitado a questöes de direito, a suprema instância jurisdicional da Comunidade". João Motas de Campos, Manual de Direito Commitário, Fundaçốo Calouste Gulbenkian, 2002 , p. 183. 
te aumentar o número de juízes do $\mathrm{TPl}^{4}$ para fazer face ao acréscimo de processos e à extensão das suas competências jurisdicionais, sem ter que alterar as disposições do Tratado. Contudo, o Tratado de Nice admite que as competências do TPI e do Tribunal de Justiça estejam sujeitas a ajustamentos pelo próprio Estatuto do Tribunal de Justiça.

As alteraçōes produzidas pelo Tratado de Nice pretendem introduzir uma maior flexibilidade ao nível da adaptação do Estatuto do Tribunal de Justiça, que poderá ser alterado pelo Conselho, deliberando por maioria qualificada e não por unanimidade, a pedido do próprio Tribunal ou da Comissão.

No que se refere aos Regulamentos de Processo do Tribunal de Justiça e do Tribunal de Primeira Instância ${ }^{6}$, estes podem ser modificados pelos próprios tribunais, mas devem ser aprovados pelo Conselho por maioria qualificada e não mais por unanimidade 7 . Essas regras processuais assumem uma importância fundamental para manter a eficácia de todo o sistema jurisdicional e uma certa coerência na jurisprudência comunitária.

Quanto ao funcionamento do Tribunal de Justiça, a nova redacção do artigo 221." do Tratado CE altera as disposiçoes relativas ao seu modo de funcionamento. O Tribunal passa a reunir-se em secções, em grande secção ou em pleno, nos casos previstos no artigo 16." do novo Estatuto do Tribunal de Justiça. De salientar ainda que, de acordo com o segundo parágrafo do artigo 221." do Tratado CE, o Tribunal de Justiça reúne-se em secções de três ou cinco juízes, em grande secção de onze juízes, entre os quais o Presidente do Tribunal cos Presidentes das secções de cinco juízes, sempre que um Estado-membro ou uma Instituição comunitária o solicite ${ }^{8}$, e também em pleno, quando considerar uma causa de excepcional importância. De entre as diversas formas de funcionamento, a secção constitui o modo normal de reunião do Tribunal.

\footnotetext{
Segulamento de Processo do Tribunal de Justiça das Comunidades Europeias de 19 de Junho de 1991.

- Regulamento de Processo do Tribunal de Primeira Instância das Comunidades Europeias de 2 de Maio de 1991.

"Artigos 223." c 224." do Tratado CE.

"A composição da grande seçăo pode originar alguma dificuldade na medida em que cria uma forma de hierarquização entre os juízes.
} 
O pleno reúne-se apenas todas as vezes que o Tribunal de Justiça seja chamado a aplicar certas disposiçóes do Tratado. Trata-se, em primeiro lugar, do caso em que o Tribunal de Justiça pode, a pedido do Parlamento Europeu, demitir o Provedor de Justiça sempre que este não exerça as suas funçōes ou haja cometido uma falta grave". Em segundo lugar, o Tribunal pode, a pedido do Conselho ou da Comissão, "ordenar a demissão compulsiva de um membro da Comissão, nos temos do artigo $216 . "$, ou a perda do seu direito a pensão ou de quaisquer outros benefícios que a substituam"10. Em terceiro lugar, o Tribunal tem a faculdade, a pedido do Conselho ou da Comissão, de demitir um membro da Comissão que deixe de preencher os requisitos necessários para o exercício das suas funçóes ou tenha cometido falta grave". Em quarto lugar, o Tribunal poderá ainda afastar os membros do Tribunal de Conlas das suas funçôes ou privá-los do direito a pensão ou de quaisquer outros benefícios que a substituam, se verificar que deixaram de corresponder às condições exigidas ou de cumprir os deveres decorrentes do cargo '? Em todas estas situações, o Tribunal só deliberará validamente com número ímpar de juízes. Ė as deliberações do tribunal pleno só serão válidas se estiverem presentes os onze juízes, enquanto que as deliberações da grande secção devem contar com a presença de nove juízes, e as deliberações das seç̧ões compostas de três ou cinco juízes necessitam de três juízes ${ }^{13}$.

No que se refere à eleição dos presidentes de secções, os juízes designam entre si os presidentes das seç̧ōes. Os presidentes das secções de cinco juízes são eleitos por três anos, podendo ser reeleitos uma vez. Os advogados-gerais não participam na eleição, apesar de serem também membros do Tribunal. Mas, a partir do momento em que os presidentes dirigem as audiências e deliberações em que participam os advogados-gerais, estes mesmos deveriam participar na eleição dos presidentes como simples eleitores ainda que sem poderem ser eleitos ${ }^{14}$.

\footnotetext{
"Artigo 195.", 11." 2, do Tratado Cl:

${ }^{10}$ Artigo $213 .{ }^{\circ}$ n." 2, do Tratado CF.

"Artigo 216. "do Tratado CL.

12Artigo 247. n. 7 , do Tratado C.

${ }^{13}$ Artigo 17." do Estatuto do Tribunal de Justiça.

14 Tribunal de Justiça das Comunidades Europeias, Relatorio sobre algans aspectos relativos à aplicąăo do Tralado sobre a União Europeia, 1995.
} 
A função dos advogados-gerais não deixa de ser importante pelo facto de terem por obrigação apresentar conclusôes gerais sobre os casos nos quais o Estatuto do Tribunal de Justiça o considere indispensável. No entanto, de acordo com o último parágrafo do artigo 20. " do novo Estatuto, sempre que o Tribunal entender não haver uma questão de direito nova, pode, após ter ouvido o advogado-geral, decidir que a causa seja julgada sem apresentação das conclusôes deste. Nos outros casos, o advogado-geral tem de ser ouvido.

Sobre esta questão, importa referir que o artigo $222^{\circ}$, n. ${ }^{\circ} 2$, do Tratado CE comete ao Estatuto do Tribunal de Justiça a determinação das causas que requerem conclusöes fundamentadas do advogado-geral. Os advogados-gerais deixam assim de apresentar conclusões sobre todos os casos, e não apenas quando o Tribunal de Justiça considerar que o caso não levanta questões de direito novas (artigo 222." do Tratado CE e artigo 20.", parágrafo 5 do Estatuto do Tribunal), o cue obriga a reenviar a decisăo para a sua apreciação colegial.

Esta disposição levanta, contudo, algumas dúvidas, na medida em que viola o princípio processual de que os acórdãos devem ser proferidos após terem sido ouvidas as conclusões do advogado-geral. A dispensa de intervenção obrigatória do advogado-geral permite, de facto, uma economia considerável de tempo e de meios no funcionamento do Tribunal de Justiça, mas, por outro lado, não garante uma boa decisão do juiz.

A razão principal que motivou a eliminação da obrigatoriedade das conclusões do advogado-geral prende-se com a tentativa de acelerar o processo. Só que, na verdade, as conclusões não têm necessariamente por efeito alargar a duração do processo uma vez que, em muitos casos, o juiz, para elaborar o seu acórdão, fundamenta-se nas conclusões do advogado-geral, o que, afinal, cncurta o tempo de decisão e concorre para que os acórdãos sejam bem fundamentados.

Em vez de uma tal medida, poder-se-ia ter fixado critérios objectivos permitindo identificar os calsos em que é exigido a apresentação de conclusões fundamentadas, ou então deixar aos advogados-gerais a faculdade de determinar onde não são exigidas tais conclusões, ou ainda atribuir aos juízes a liberdade de requerer conclusões quando julgem que elas são necessárias para a solução do litígio.

O Estatuto do Tribunal optou por uma outra via, prevendo no artigo 
20." que, "quando considerar que näo se suscita questão de direito nova, o Tribunal pode, ouvindo o advogado-geral, decidir que a causa seja julgada sem conclusões do advogado-geral". As conclusões são assim facultativas a não ser que surja uma questão de direito nova, ou uma noção jurídica indeterminada susceptível de originar várias interpretaçōes. Esta regra foi adoptada sem que os advogados-gerais tenham sido consultados, confirmando, uma ve zais, o carácter subsidiário da sua função, relegados para um papel secundário, para um cargo de funcionário de serviço, de investigador ou de documentalista.

Como outra alteração importante adoptada pelo Tratado de Nice avulta a modificação do artigo 220." do Tratado CE que visa associar o TPI à missão fundamental de garantir "o respeito do direito na interpretação c aplicação do presente tratado" e de repartir as competências entre os dois tribunais.

A nova repartição de competências entre o Tribunal de Justiça e o TPI consagrada no artigo 225." do Tratado CE parece atribuir a este último uma competência geral para conhecer em primeira instância dos recursos directos, à excepção daqueles atribuídos à competência de uma câmara jurisdicional, dos recursos por omissão dirigidos contra os Estados-membros, e aqueles que o Estatuto reserva à competencia do Tribunal de Justiça. O mesmo artigo dispõe que o Estatuto pode prever que o TPI seja competente para outras categorias de recursos, sem nada especificar sobre os tipos destes. Em relação a esta questão, o artigo 51.0 do Estatuto do Tribunal dispõe que, "em derrogação da regra enunciada no n." I do artigo 225." do Tratado CE (...), são da competência do Tribunal de Justiça as acções propostas e os recursos interpostos pelos Estados-membros, pelas Instituições das Comunidades e pelo Banco Central Europeu". Resulta destas disposições alguma confusão do ponto de vista da técnica legislativa, que não contribui seguramente para uma repartição equilibrada das competências, na medida em que o artigo 51." derroga o estabelecido no 225."

Uma vez ajustada a questão da repartição de competências entre o Tribunal de Justiça e o TPI, o legislador comunitário entendeu criar câmaras jurisdicionais para apreciar em primeira instância determinadas categorias de acçôes em domínios específicos e fazer face ao aumento regular de processos. O novo artigo 225."-A do TCE estabelece que "o Conselho, deliberando por unanimidade, sob proposta da Comissão e 
após consulta ao Parlamento Europeu e ao Tribunal de Justiça, ou a pedido do Tribunal de Justiça c após consulta ao Parlamento Europeu e à Comissão, pode criar câmaras jurisdicionais encarregadas de conhecer em primeira instância certas categorias de recursos, em matérias específicas".

Prevê-se, portanto, uma ligaçăo das câmaras jurisdicionais ao TPI, considerando que as câmaras fazem parte integrante do órgão jurisdicional e participam plenamente no poder de decisão judiciário, apesar de beneficiarem de uma total independência nas matérias da sua competência específica.

Essa independência traduz-se na faculdade de tomar decisões sobre os assuntos que thes dizem respeito. Isto não invalida o facto de as decisões poderem ser objecto de recurso para o TPI, conforme a nova redacção do artigo $225 .^{\circ}$, n. $^{\circ} 2$, c o novo artigo $225 .^{\circ}-$ A do Tratado CE. É o caso, por exemplo, das decisões que as câmaras jurisdicionais podem adoptar em matéria de propriedade industrial ${ }^{15}$ e que são susceptíveis de serem reapreciadas pelo Tribunal de Justiça ${ }^{16}$. O Tratado de Nice prevê efectivamente que as decisões proferidas pelas câmaras jurisdicionais sejam objecto de recurso para o TPI ou eventualmente reapreciadas a lítulo excepcional pelo Tribunal de Justiça caso exista um risco grave de lesão da unidade ou da coerência do direito comunitário ${ }^{17}$.

O Tratado de Nice procede a uma verdadeira reorganização do sistema jurisdicional comunitário, redefinindo as competências do Tribu-

\footnotetext{
15 O artigo 229." A do Tratado CE prevê que "sem prejuízo das restantes disposiçōes do presente Tratado, o Conselho, defiberando por unanimidade, sob proposta da Comissăo e após consulta do Parlamento Europeu, pode aprovar disposiçóes destinadas a atribuir ao Tribunal de Justiça, na medida determinada pelo Conselho, competencia para decidir sobre litígios ligados à aplicação dos actos adoptados com base no presente Tratado que criem títulos comunitários de propriedade industrial. O Conselho recomendará a adopęão dessas disposições pelos Estados-membros, de acordo com as respectivas normas constitucionais". Este novo artigo permite ao Consclho, deliberando por unanimidade, atribuir ao 'Tribunal de Justiça competência para apreciar os litígios relativos à propriedade industrial. 'lal disposição visa essencialmente os contenciosos entre particulares ligados à aplicaçăo dos actos adoptados com base no 'Tratado que criem lítulos comunitários de propriedade industrial. Esta decisão do Conselho apenas cotrará em vigor após a sua adopção pelos Estados-membros.

16 Artigo 225.", n." 2 e 3 , do Tratado CH.

${ }^{17}$ Artigo 225." n." 2, do Tratado CF.
} 
nal de Justiça e do TPI, e atribuindo competências às novas câmaras jurisdicionais.

O Tribunal de Justiça c o TPI passam a ser os guardiōes da ordem jurídica comunitária, conforme as competências previstas no Tratado de Nice e nos Estatutos de Regulamento dos respectivos tribunais, na medida em que participam activamente na consolidação da ordem jurídica comunitária e na afirmação da primazia do direito comunitário sobre o direito dos Estados-membros.

Para manter a eficácia e a viabilidade do sistema foi necessário proceder a importantes alterações ao nível do funcionamento do sistema jurisdicional's e reforçar, em particular, as compctências dos órgãos jurisdicionais.

\section{A COMPETÊNCIA DOS ÓRG ÃOS JUDICIÁRIOS DO SISTEMA COMUNITÁRIO}

\subsection{As competências gerais do Tribunal de Justiça}

Ao Tribunal de Justiça foram atribuídas competências consultiva e contenciosa.

No âmbito da sua competência consultiva, o Tribunal de Justiça pode ser solicitado, pelos tribunais nacionais, a interpretar o direito comunitário ou apreciar a validade dos actos das instituiçoes comunitárias. Esta competencia assenta na relação entre a jurisdição comunitária e as jurisdições nacionais.

Sempre que o juiz nacional tenha dúvidas sobre a interpretação de uma norma comunitária ou a validade do acto comunitário num caso apresentado por um dos demandantes, compete alo juiz comunitário decidir, a título prejudicial, sobre a interpretação da norma ou a validade do acto comunitário.

\footnotetext{
${ }^{8}$ Carlos Botetho Moniz (responsável pelo grupo de trabalho), Andreia Soares, Maria João Fencira, Eduardo Henriques, Miguel Fontoura, O Thatado de Nice e o futuro da Uniăo Europeia, Estudo elaborado a solicitação da Assembleia da República, Lisboa, 31 de Julho de: 2001, pp. 57.59.
} 
Cabe, en seguida, aos juízes nacionais aplicar o direito comunitário conforme resulta da sua interpretação pelo juiz comunilário.

Em todo o caso, os tribunais nacionais ... cm última instância - são obrigados a solicitar ao TJ que thes forneça a correcta interpretação da norma comunitária ou que se pronuncie sobre a validade do acto comunilário ${ }^{19}$. Após se ter pronunciado, a decisão do 'TJ é vinculativa para o juí nacional que solicitou a questão prejudicial de interpretação ou de apreciação de validade (cf. o artigo 234. do Tratado CE). A função das jurisdiçöes nacionais é garantir a unidade e coerência na aplicação do direito comunitário em todo o espaço curopeu, como tribunais comuns da ordem jurídica comunitária.

A competência contenciosa exerce-a o Tribunal de Justiça que, nos termos do artigo 220. " do Tratado $\mathrm{CE}$, deve garantir «o respeito do direito na interpretação e aplicação» dos Tratados e a salvaguarda da ordem jurídica comunitária.

No âmbito desta competência, o Tribunal de Justiça pode, a pedido da Comissão, de um Fstadomembro, do Conselho de Administração do Banco Europeu de Investimento ou do Conselho do Banco Central Europeu, julgar uma acção por incumprimento c a violação por parte de um Estado-membro das obrigações decorrentes do direito comunitário ${ }^{20}$. Tribunal de Justiça garante assim, alravés da acção por incumprimento, uma aplicação uniforme do direilo comunitário.

Também ao Tribunal de Justiça pode ser solicitada a resolução, no âmbito de un recurso de anulação ou recurso por omissão, de conflitos de competência entre as Instituições Comunitárias ou ainda para controlar a conformidade dos actos ou das abstenções destas últimas em relação às obrigações constantes dos Tratados - artigos $230 .^{\circ} \mathrm{e}$ 232." do Tratado CE - e aos princípios gerais de dircito conunitário.

O Tribunal de Justiça, no uso das suas competências, detém, por exemplo, toda a legitimidade para apreciar a legalidade dos actos administativos praticados pelas Instituiçōes Comunitárias ou conhe-

\footnotetext{
1" E de notar que 80\% das questõos prejudiciais cmanam de jurisdições que não săo jurisdiçoes macionais supremas, Relatorio O. DUE sobre o futuro do sistema jurisdicional da Uniăo Europcia, cnviado para o Conselho em lo de Maio de 1999, Il.A.1.a.

"Artigos 226." a 228.", 237.", a), 88.", n." 2, e 292." do "Tratado Ct.
} 
cer ainda dos litígios que as opõem aos seus funcionários e agentes ${ }^{21}$.

Finalmente, o Tribunal de Justiça detém competência para julgar certos comportamentos dos operadores do Mercado Comum²2, aplicar sanções pecuniárias ${ }^{23}$, decidir da responsabilidade extracontratual da Comunidade nos termos dos artigos $235^{\circ}$ e $288 .^{\circ}$ do Tratado CE, conhecer das questōes aduaneiras ou fiscais decorrentes da aplicação das disposiçóes dos Tratados ou do direito derivado, e ainda apreciar os litígios que the são submetidos, quer cm virtude de uma cláusula compromissória constante de um contrato de direito público ou de direito privado, quer por força de um acto unilateral ou de uma convenção concluída pela Comunidade ${ }^{24}$.

\subsection{O Tribunal de Justiça como guardião da unidade e coerência do direito comunitário}

Como guardião da unidade e da coerência do direito comunitário, ao Tribunal de Justiça cabe a função essencial de garantir a interpretação e aplicação uniforme das regras de dircito comunitário, através, entre outros, do mecanismo do reenvio prejudicial.

Hoje, esta competência em matéria de questões prejudiciais é partilhada com o TPI, que passa a conhecer de certas questöes prejudiciais, pois o artigo $225 .^{\circ}$ do Tratado Clí considera que o TPl ć competente para conhecer das matérias específicas fixadas pelo Estatuto do Tribunal. Deste modo, o TPI passa igualmente assume igualmente a função de guardião da unidade e da coerência do direito comunitário.

O Tribunal de Justiça não deixa contudo de exercer a função essencial de supremo tribunal da União Europeia e de tribunal constitucional do direito comunitário, uma vez que se assume como o guardião da unidade e coerência do direito comunitárión ${ }^{25}$. O Tribunal de Justiça, situado no topo da organização judiciária como supremo tribunal da Uniăo Europeia, exerce uma competência exclusiva em certas matérias

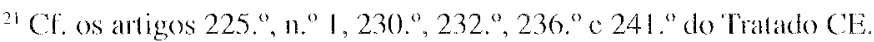

2 Cf., por exemplo, os artigos 81.0 e $82 . "$ do Tratado CH.

"2. Artigos 228.", n." 2, e 229." do Thatado CF.

2 Arligos 238." e 239." Tratado CF.

$2 \mathrm{~V}$. artigo 62, do Estatuto do Tribunal de Justiça.
} 
fundamentais para a ordem jurídica comunitária.

Daí poder concluir-se que o Tribunal de Justiça exerce verdadeiras funções constitucionais no que se refere ao poder de controlo da unidade e coerência do direito comunitário, à repartição de competências entre a União Europeia e os Estados-membros, à apreciação das disposições dos Tratados, à definição e salvaguarda dos princípios gerais da ordem jurídica comunitária, ao controlo da constitucionalidade do direito comunitário, à salvaguarda do equilíbrio institucional, ao controlo da constitucionalidade das convenções celebradas pela União Europeia e à protecção dos direitos fundamentais ${ }^{2 t}$.

Saliente-se, especialmente, a extensão das competências do Tribunal de Justiça em certos domínios. Por exemplo, o artigo 46.", al. e), do Tratado CE confere-lhe a faculdade de se pronunciar sobre o conteúdo do artigo 7. "do Tratado CE, isto é, sobre a suspensão de alguns direitos decorrentes do Tratado CE cm relação a um Estado-membro que tenha cometido una violação grave e persistente dos princípios previstos no artigo 6." n." I, relativos à liberdade, democracia, direitos do Homem e liberdades fundamentais. O Tribunal pode aqui pronunciar-se, a pedido do Estado-membro en questão, no prazo de um mês a contar da data da constatação por parte do Conselho, sobre a existência de um risco de violação grave do direito comunitário.

\section{AS COMPETENCIAS DO TRIBUNAL DE PRIMEIRA INSTÂNCIA}

\subsection{O TPI como juiz de direito comum}

O legislador comunitário entendeu reforçar a competência do TPI para permitit que o TJ concentre a sua actividade na função essencial de assegurar a interpretação uniforme do direito comunitário ${ }^{27}$ e controlar o respeito do mesmo por parte das instituições comunitárias e dos

\footnotetext{
${ }^{6}$ Dámaso Ruz Jarabo, « la réforme de la Cour de lustice opérée par te traté de Nice et sa mise en ocuvre future », Revue trimestrielle de droit européen, Paris, a $37, n^{\circ} 4$, oct. -déc. 2001 , p. 723.

27 Artigos 220." e 234." Tratado Cl:
} 


\section{Estados-membros.}

Tal como já foi referido, o TPI apresenta-se hoje como uma jurisdição de direito comum com competência para julgar os recursos directos e certas matérias específicas.

Várias matérias específicas - para além do contencioso da função pública - transitaram para a competência do TPI, como o contencioso da propriedade intelectual, as matérias referentes ao terceiro pilar e ao título IV do Tratado CE ou o contencioso da concorrência.

O TPI detém hoje competência para conhecer cm primeira instância dos recursos referidos nos artigos 230.", 232.", 235.", 236.", 238." do Tratado CE, com excepção dos atribuídos a uma câmara jurisdicional e dos que o Estatuto reservar ao Tribunal de Justiça ${ }^{28}$. Neste sentido, o TPI apresenta-se como uma jurisdição de direito comum para o conjunto das acções directas - recursos de anulação (artigo 230..$^{\circ}$ ), as acções por omissão (artigo 232. ${ }^{\circ}$ ), as acções de indemnização, por responsabilidade extracontratual da Comunidade Europeia (artigo 235."), o contencioso da função pública europcia (artigo 236."), c o contencioso relativo aos contratos celebrados pela União, em virtude de cláusulas compromissórias atributivas de competência (artigo 238."). O TPI só não scrá competente no caso de a competência em causa ser atribuída a uma câmara jurisdicional ou ao Tribunal de Justiça ${ }^{29}$.

O TPI pode perfeitamente conhecer dos recursos interpostos contra as decisões das câmaras jurisdicionais, as quais, em casos excepcionais, constituirão objecto de um recurso directo para o Tribunal de Justiça. O 'TPI tem, de facto, competência para "conhecer dos recursos interpostos contra as decisões das câmaras jurisdicionais criadas nos termos do artigo 225."-A do Tratado", as quais estão "encarregadas de conhecer em primeira instância certas categorias de recursos em matérias especílicas". E ć encarado como uma jurisdição de direito comum com competência para apreciar diversas categorias de recursos directos, mas também, como veremos adiante, certas questões prejudiciais e matérias específicas da sua competência. Tal não significa que as decisóes do TPI não sejam eventualmentc objecto de recurso para o Tribunal de Justiça. Este último tem efectivamente toda a competência para, nalguns casos,

\footnotetext{
*Artigo 225.", n." 1, do Tratado CE.

".9 Paula Vaz Freire, Os Nowos Passos da Imegraşäo Europeia, VISL IS, 2002, p. 145
} 
reapreciar as decisóes do TPl, limitadas às questões de direito.

\subsection{O funcionamento do TPI com um juiz singular}

\subsubsection{A competência do juiz singular}

Tal como resulta do Tratado de Nice, o TPI pode funcionar por secęôes, compostas por três ou cinco juíres, sendo a composição das secçoes e a distribuição das causas fixadas pelo Regulamento de Processo.

O TPI, conforme já mencionado, reunir-se-á e deliberará em grande seceão, de acordo com o estatuído no Regulamento de Processo do Tribunal de Justiça, ou em sessão plenária, ou funcionará, por último, com juiz singular ${ }^{3 !}$.

A possibilidade de o TPI luncionar com juiz singular foi implementada para fazer face ao excesso de processos que congestionam os tribunais comunitários ${ }^{31}$. O artigo 14." do Regulamento de Processo do TPl prevê, mais concretamente, que as causas atribuídas a uma secção de três juízes podem ser julgadas por um juiz relator que decide como juiz singular. O juiz singular passa a ser o juiz relator da causa, nas secções de três juízes.

A atribuição de uma calusa a um juiz singular deve ser decidida por unanimidade pelos três juizes da secção após as partes terem sido ouvidas. Mas se um Estado-membro ou uma instituição comunitária parte no processo se opuser à constituição de um juiz singular, o caso é então julgado pela secção de três juízes, na qual fáz também parte o juiz singular.

Na realidade, o juiz singular só pode decidir nos três casos especificamente previstos no artigo 14.", n." 2, al. 1, do Regulamento de Processo do TPI.

Em primeiro lugar, ele intervém nos casos de litígios entre a União

\footnotetext{
"Artigo 50." do Protocolo relativo ao Lstatuto do 'l'ribunal de Justiça.

3 Este novo sistema do juiz único ou singular resulta de uma decisão do Conselho de 26 de Abril de 1999 que vem alterar o Regulamento de Proesso do TPl. Fin 17 de Maio de 1999 o TPl proceden às alteraçoes necessárias do Regulamento para introduzir um tal sistema.
} 
Europeia e os seus funcionários ${ }^{32}$.

Em segundo lugar, julga os recursos directos introduzidos pelas pessoas singulares ou colectivas contra as decisões do Parlamento Europeu, Conselho, Comissão ou Banco Central Europeu ${ }^{3.3}$.

Em terceiro lugar, aprecia os casos em que o TPI é competente para julgar o contencioso relativo aos contratos celebrados pela União Europeia com base numa cláusula compromissória atributiva de competência ${ }^{34}$. A competência atribuída ao juiz singular apresenta contudo algumas limitações, que não podemos deixar de referir.

\subsubsection{As competências limitadas do juiz singular}

Há casos en que o juiz singular está proibido de julgar: $\mathrm{O}$ artigo 14.", n." 2, al. 2, do Regulamento de Processo do TPI contempla precisamente uma série de hipóteses em que o juiz singular não está autorizado a julgar. Trata-se dos casos relativos à legalidade de um acto genérico, à implementação das regras de concorrência e de controlo das concentraçoóes, às regras relativas aos auxílios públicos, às medidas de defesa comercial e à organização comum dos mercados agrícolas, e os casos que dizem respeito aos recursos dirigidos contra o Instituto de Harmonização do Mercado Interno (marcas e patentes, desenhos e modelos) e contra o Instituto Comunitário das Variedades Vegetais ${ }^{35}$. O mesmo acontece com o direito de acesso dos cidadãos aos documentos detidos pelas instituições comunitárias ${ }^{36}$.

Esses casos não podem ser julgados por um juiz singular dada a importância que revestem essas questões para a União Europeia, o que

\footnotetext{
32 Artigo 236." do Tratado CH.

${ }^{33}$ Artigos 230.", 232." e 235." do Tratado Cli.

"Arligo 238." do Tratado CL.

${ }^{35}$ Artigo 63." do Regulamento n." 40/94 do Conselho de 20 de Dezembro de 1993 sobre a marca comunitária e JOCF L, 11, de 14 de Janeiro de 1994, p. 1, c o artigo 130 do Regulamento de Processo do TPI, tal como allerado a 6 de Julho de 1905 (IOCE L, 172 , de 22 de Julho de 1995, p. 3).

"36 D.M. Curtin, «Citizens fundamental right of acess to EU information: An cvolving digital passepartout?», Common Market Law Review, 37, 2000, pp. 7-41. Paolo Mengo7æi, "le Tribunal de première instance des Communautés curopécunes el la protection juridique des particuliers", I/ diritto dell'Unione Luropea, v. 4, 1999, pp. 181-205.
} 
limita obviamente a função do juiz singular e põe cm causa a sua institucionalização.

Na prática, a função do juiz singular tem uma eficácia limitada na medida cm que, por exemplo, é incompetente para julgar os litígios relativos ao direito da concorrência, auxilios públicos e controlo das situações de monopólio. Tais domínios năo fazem parte integrante da competência rationac moteriac do juiz singular.

Além disso, of funcionamento do TPI com um juiz singular está subordinado à vontade de um Estado-membro ou de uma instituição comunitária, que podem perfeitamente recusar a implementação de um tal sistemá.

A sua eficácia será também reduzida pela circunstância de a decisão de atribuir uma causa a um só juiz ter de ser tomada por unanimidade da secção, o que obriga os juizes, antes de votar, a ter conhecimento do caso para saber se devem ou não devolvê-to ao juiz singular. Toda a secçăo acaba por apreciar, pelo menos parcialmente, o caso em questão antes de o transferir para o juiz singular. Um tal sistema não permite diminuir a duração dos processos no TPI.

Nalguns casos, assistir-se-á até a uma dilação do prazo do processo. Porque se o juiz singular decidir reenviar o caso para a secção, considerando que não estão reunidas as condiçôes para que possa decidir, a causa acaba por não ser julgada num prazo razoável.

Una das outras lacunas do sistema do juiz singular advém do facto de, no momento de o juiz se pronunciar individualmente sobre a causa, não existir a possibilidade de discussão entre o próprio juiz singular e os outros juízes, violando-se assim o princípio da colegialidade que permitiria promover uma comparação entre os diversos sistemas jurídicos nacionais, de modo a evitar uma identificação ou redução a um deles ${ }^{37}$. Trata-se aqui de evitar que o juiz singular adopte decisões contrárias à jurisprudência estabelecida pelo TPl.

A jurisdição singular surge como uma solução que não contribui para um melhoramento do sistema jurisdicional comunitário. A possi-

\footnotetext{
37 Rodolphe Muño/, «L système de juge unique pour le règlement d'un problème multiple : l'encombrement de la Cour de Justice des Communautés Européennes et du Tribumal de Première Instance », Réue du Marché Commun é de l'Union Européenne, n." 444, Jancito, 2001 , p. 63.
} 
bilidade para o TPI de funcionar com juiz singular perdeu aliás todo o seu interesse, uma vez que estão a ser criadas câmaras jurisdicionais ou tribunais especializados para resolver muito dos conflitos.

\subsection{O recurso das decisões do TPI para o Tribunal de Justiça}

As decisões proferidas pelo TPI são susceptiveis de serem apreciadas pelo Tribunal de Justiça através da interposição de um recurso. O artigo 225." do Tratado CE prevê que as decisóes do TPI possam ser objecto de recurso para o Tribunal de Justiça, limitado às questões de direito, nas condições previstas pelo Estatuto do Tribunal. As decisões do TPI admitem recurso para o Tribunal de Justiça, de acordo com o disposto no respectivo Estatuto.

Por força do artigo 49." do Estatuto, «pode ser interposto recurso para o Tribunal de Justiça das decisóes do TPI que ponham termo à instância, bem como das decisões que apenas se pronunciem parcialmente sobre o mérito da causa, ou que ponham termo a um incidente processual relativo a uma excepção de incompetência ou de inadmissibilidade. O recurso deve ser interposto no prazo de dois meses a contar da notificação da decisão impugnada».

Também, em virtude do artigo 50." do Estatuto, pode ser interposto recurso para o Tribunal de Justiça do indeferimento pelo TPI de um pedido de uma intervenção em processo pendente e das decisões do TPI tomadas ao abrigo do disposto nos artigos $242 .^{\circ}$ ou $243 .^{\circ}$ ou no quarto parágrafo, do artigo 256." do Tratado CE.

Tem legitimidade para recorrer, segundo o art." 49." do Estatuto, qualquer das partes que tenha sido total ou parcialmente vencida. Todavia, as partes intervenientes que não sejam os Estados-membros e as Instituições da Comunidade só podem recorrer se a decisão do TPI as afectar directamente. Com excepção dos litígios entre a Comunidade e os seus agentes, este recurso pode igualmente ser interposto pelos Estados-membros e Instituiçóes das Comunidades que tenham intervindo no litígio perante o TPI.

E mesmo quando as partes no processo perante o TPI tenham aceitado o acórdão proferido por este último, os recorrentes privilegiados podent sempre recorrer para o Tribunal de Justiça, a lim de preservar a 
coerência da jurisprudência ou requerer a sua uniformização.

Em todo o caso, os recorrentes devem apresentar uma petição ao Tribunal de Justiça nos termos previstos no Estatuto, isto é, no prazo de dois meses a contar da notificação da decisão impugnada (art." 49." do Estatuto) - prazo apenas de duas semanas no caso de recurso do indeferimento do pedido de intervenção (art. 50.", primeiro parágrafo, do Estatuto).

Pode ser assim interposto recurso para o 'Tribunal de Justiça das decisões do TPI que ponham termo à instância, bem como das decisões que apenas se pronunciem parcialmente sobre o mérito da causa ou que ponham termo a um incidente processual relativo a uma excepção de incompetência ou inadmissibilidade (art." 49." do Estatuto do Tribunal).

Na sua petição, o recorrente deverá especificar o objecto do recurso, pedindo a anulação total ou parcial da decisão do TPI, o provimento, no todo ou em parte, dos pedidos que tenham sido apresentados no tribunal «a quo», não sendo permitido, pois, formular pedidos novos ou modificar o objecto do litígio tal como foi apresentado ao TPI ${ }^{38}$.

Resulta dos artigos 225." do Tratado CE e $51 .{ }^{\circ}$, n." 1, do Estatuto do Tribunal de Justiça que o recurso se há-de limitar às questôes de direito, ter por fundamento a incompetência do TPI, irregularidades processuais que prejudiquem os interesses do recorrente, bem como a violação do direito comunitário. Esses são os fundamentos do recurso passíveis de serem invocados pelo recorrente.

Uma vez que o TPl apurou e apreciou os factos ${ }^{39}$, o Tribunal de Justiça não pode reapreciá-los, devendo accitá-tos tal como apurados pelo Tribunal a quo ${ }^{41}$. No entanto, o Tribunal de Justiça năo deixa de exercer um controlo sobre a qualificação jurídica desses factos se, na obtenção das provas, for violada uma disposição ou um princípio geral de direito comunitário ou se for efectuado uma apreciaçăo crada dos elementos de prova.

Conforme dispõe o artigo 225." do Tratado CE, mesmo que o TPI

\footnotetext{
38 Artigo 113." do Regulamento do Tribunal.

"3) O TPl é o único competente para apuar e apreciar a matéta de lacto a partir dos elementos de prova disponíveis.

40 Artigo 112.", n." I, al. c), do Regulamento de Processo do Tribunal de Justiça.
} 
tenha apreciado os factos, o Tribunal de Justiça pode sempre exercer a fiscalização da qualificação jurídica dos mesmos e das consequências jurídicas que deles resultam.

Também no momento de apreciar o pedido de revisão da decisão adoptada em primeira instância, o Tribunal de Justiça não se deve limitar a reproduzir textualmente os fundamentos e os argumentos apresentados. Há-de analisar essencialmente os fundamentos que constituem uma violação das regras de direito.

Tal como resulta dos artigos $113 .^{\circ}$, n." 2, c $116 .{ }^{\circ}$, n. ${ }^{\circ} 1$, do Regulamento de Processo, não podem ser apresentados no recurso para o Tribunal de Justiça fundamentos novos (que não tenham sido anteriormente apreciados pelo TPI). O Tribunal de Justiça encontra-se assim limitado aos fundamentos apresentados ao TPI, nấo podendo modificar o objecto inicial do litígio.

Tendo o TPI violado o direito comunitário ao rejcitar, por exemplo, os fundamentos e os argumentos do recorrente, essas questöes deverão ser novamente discutidas em sede de recurso de anulação.

Na fase final do julgamento do recurso, após a apresentação dos articulados e do relatório do juiz-relator, se o recurso não for julgado inadmissível, o Tribunal, ouvido o advogado-geral e as partes, pode decidir prescindir da fase oral do processo, salvo se uma das partes apresentar um pedido justificativo das razões por que entende dever ser ouvida em audiência (artigos 120." e 121."). Com ou sem fase oral, o Tribunal aprecia o recurso, julgando-o procedente ou improcedente, decidindo finalmente sobre as custas (artigo 122. ${ }^{\circ}$ ).

\subsection{A competência do TPI em nıatéria prejudicial}

\subsubsection{A articulação entre o Tribunal de Justiça e o TPI}

O Tratado de Nice procede a uma transferência das questões prejudiciais do Tribunal de Justiça para o TPI, prevendo assim que este intervenha no mecanismo do reenvio prejudicial, em certas matérias específicas, que não vêm, aliás, previstas no Estatuto do Tribunal de Justiça.

O Tratado de Nice atribui ao TPI, tal como ao Tribunal de Justiça, competência para garantir «o respeito do direito na interpretação e 
aplicação do presente Tratado» ${ }^{41}$. O Tratado admite que o TPI aprecie igual mente as questões prejudiciais que the sejam submetidas por força do artigo 234." do Tratado CE ${ }^{42}$, em matérias específicas determinadas pelo Estatuto do Tribunal. O Tratado prevê igualmente que as decisöes proferidas scjam excepcionalmente objecto de recurso para o Tribunal de Justiça no caso de estar em causasa a unidade ou a coerência do direito comunitário ${ }^{43}$.

O facto de o Tratado de Nice introduzir a possibilidade do TPI conhecer das questões prejudiciais formuladas pelos tribunais nacionais, em matérias fixadas pelo Estatuto, faz com que o Tribunal de Justiça perca a exclusividade cm matéria de interpretação c aplicação uniforme do direito comunitário. O Tribunal de Justiça deixa assim de apreciar todos os processos de reenvio prejudicial ${ }^{44}$.

Tal não impede que as decisöes do TPI sobre questöes prejudiciais sejam excepcionalmente reapreciadas pelo Tribunal de Justiça estando em causa uma decisão de princípio, susceptível de afectar a unidade e coerência do direito comunitário. O último parágrafo do artigo 225.", n." 3, do TCE aponta precisamente no sentido de o Tribunal de Justiça poder reapreciar as decisóes prejudiciais proferidas pelo TPI.

O TPI acaba, nestes termos, por assumir a função de um tribunal constitucional no ordenamento jurídico comunitário, através do artigo 220. "do Tratado CE que dispöe que o TPI garante «o respeito do direito na interpretação e aplicação do presente Tratado». Resulta, pois, do artigo 220. " que o dircito comunitário não é definido apenas pelo Tribunal de Justiça, mas também pelo TPI que, associado ao Tribunal de Justiça,

\footnotetext{
4 Artigo 220." do Tratado (E.

"O processo do reenvio prejudicial, bascado no artigo 234." do Tratado, permite a qualquer órgão jurisdicional de um Fstado-membro ao qual tenha sido submetida uma questão sobre a aplicaçăo do direito comunitário, de suscitar petante o Tribunal de Jus tiça una questão de interpretação do direito em causa para resolver o litígio. O reenvio dessa questão prejudicial é obrigatótio, salvo no caso de a questão náo ser considerada pertinente on a disposiçäo comunitária já ter sido objecto de interpretaçäo por parte do Tribunal de Justiça ou anda a aplicą̧ăo do direito comunitário năo levantar qualquer dúvida.

4. Artigos 225." n." 3, do Thatado Cle 62." do Estatuto.

4 Olivier Dubos, "Quel avenir pout le Tribunal de première instance après le traité de Nice ? », Revue des Affaress Emopéennes, n." 4, 2000), p. 429.
} 
exerce competências jurisdicionais de ordem "constitucional"45. Este artigo foi considerado pelo Tribunal de Justiça, num parecer sobre o Espaço Económico Europeu de 14 de Dezembro de $1991^{46}$, como uma disposição de natureza "supraconstitucional". E representa, de facto, um elemento essencial para a autonomia da ordem jurídica comunitária, um contributo indispensável para a afirmação da "comunidade de direito", conceito que permitiu ao Tribunal de Justiça caracterizar a natureza da ordem jurídica comunitária ${ }^{17}$.

Este acréscimo de competências a favor do TPI deve ser obvianente acompanhado de uma perfeita articulação com o Tribunal de Justiça, que se mantém como o responsável principal da unidade e coerência do direito comunitário. O Tribunal de Justiça continua, pois, a assumir o papel de órgão constitucional da União, de garante da unidade do sistema comunitário e dos direitos fundamentais nele consagrados, enquanto que o TPI reforçado passa a exercer a função de jurisdição comum de primeira instância, com uma competência geral alargada para poder apreciar certas matérias específicas definidas pelo Estatuto.

\subsubsection{O tratamento da questão prejudicial pelo TPI}

A circunstância de o TPI se tornar competente para apreciar as questôes prejudiciais en certos domínios específicos não impede, como já foi referido, o Tribunal de Justiça de exercer um controlo sobre a actividade do TPl mesmo em matéria prejudicial, a fim de garantir uma interpretação autêntica e uma aplicação uniforme de todo o direito comunitário na ordem jurídica dos Estados-membros.

Sempre que o TPI considera que a questão prejudicial exige "uma decisão de princípio susceptível de afectar a unidade ou coerência do direito comunitário", deverá remetê-la ao 'Tribunal de Justiça para que delibere sobre a causa. As decisões do TPI sobre questôes prejudiciais

\footnotetext{
45 Olivice Dubos, ob cit, p. 431.

th Parecer do TICF, 14 de Dezembro de 1991, Projecto de acordo entre a Comunidade c os paŕses da Associação Europeia de Comércio Livre sobre a criação do Espaço Económico Europeu, caso C-1/91, Rec., p. 1-6079.

17 TJCE, 23 de Abril de 1986, Partido ecológico "Os verdes" c/ Parlamento europeu, caso 294/83, Rec., p. 1339
} 
podem ser reexaminadas pelo Tribunal de Justiça nas condições e nos limites previstos pelo Estatuto, c no caso de ameaça à unidade e coerência do direito comunitário.

O TPI deve deixar de exercer a sua competência prejudicial para que o Tribunal de Justiça adopte uma decisão de princípio susceptível de afectar a unidade ou a coerência do direito comunitário ${ }^{48}$. O TPI vê, destarte, a sua competência afastada para que seja assegurada a unidade ou coerência do direito comunitário. O Tribunal de Justiça, como supremo tribunal comunitário, limita a intervenção do TPI aos casos previstos no Estatuto.

A repartição de competências entre as duas instâncias reveste uma importância fundamental por causa do número cada vez mais elevado de questöes prejudiciais apresentadas, do desenvolvimento do contencioso comunitário ${ }^{49}$, e da duração dos prazos processuais que muitas vezes não são respeitados ${ }^{50}$.

Sucede, com efeito, que nem sempre os processos săo julgados num prazo razoável, tal como o prevê o artigo 6.", n" I da Convenção Europeia dos Direitos do Homem. Foi assim que no caso Baustahlgewebe GmbH c/ Comissão Europeia ${ }^{51}$, o próprio Tribunal de Justi-

4. Artigo 225.", 11." 3, do Tratado CH.

49 $\mathrm{O}$ aumento de processos registados pode observar-se em todos os domínios do contencioso. Em 2003, o numero de processos novos chegados ao Tribunal de Justiça foi de $561(477$ em 2002). () número de processos pendentes no fim de 2003 é de 974 , quando, no final de 2002 , era de 907 . No TPI, os processos relativos a duas matérias específicas, a saber, o contencioso da função pública comunitária e o da propriedade intelectual, re presentam mais de $50 \%$ do contencioso que deu entrada no TPI. Cfr. Tribunal de Justiça das Comuniclades Europeias, Relatório anual 2003: síntese dos trabalhos do Tribunal de Justiça e do Tribunal de Primeina Instância das Comunidades Europeias, Luxemburgo, $2004, p p .9$ e 109 . No que se refere aos processos de reenvio prejudicial, o númoro de recnvios entrados no Tribunal de Justiça aumentou $87 \%$ de 1990 a 1998.

so Regista-se uma tendência para o prolongamento da duração dos processos. Relativamente aos pedidos de decisẫo prejudicial c às acçôes e recursos directos, essa duraçẫo foi de cerca de 25 meses em 2003, quando, em 2002, cra de cerca de 24 meses. A duração média dos processos de recurso de decisöes do TPl foi de 28 meses em 2003 (tinha sido de 19 meses em 2002). Cfr. Tribunal de Justiça das Comunidades Europeias, Relatorio anual 2003: sintese dos trabalhos do Tribunal de Jastiça do Tribunal de Primeira Instância das Combnidades Luropeias, Luxemburgo, 2004, p. 9.

st TJCE, 17 de Dezembro de 1998, Baustahlgewebe CimbH c/ Comissão Europecia, caso C. $-185 / 95$ P', Rec., p. 1-8417. 
ça admitiu que tinha violado o direito a um julgamento num prazo razoável, reconhecendo expressamente uma violação do artigo 6.", n." I. Trata-se de uma questão sensível susceptível de vir a agravar-se com o aumento progressivo do número de processos de reenvio prejudicial, do desenvolvimento da actividade da União Europeia e do aprofundamento das suas competênciass ${ }^{52}$.

Ora, a atribuição ao TPI de uma competência prejudicial conduzirá porventura ao alargamento dos prazos dos processos em matéria de reenvio prejudicial, e levanta a questão da autoridade das sentenças proferidas em primeira instância, as quais podem ser reapreciadas pelo Tribunal de Justiça. Também a circunstância de o 'Tribunal de Justiça e do TPI serem ambos competentes para conhecer das questóes prejudiciais pode pôr em causa a coerência da jurisprudência comunitária, criar alguma confusão, e não assegurar adequadamente os direitos dos recorrentes.

A introdução de um sistema de duplo grau de jurisdição ${ }^{53}$ nos pro. cessos de reenvio prejudicial, eventualmente, não só alterará as características do sistema jurisdicional, que foi inicialmente pensado para uma única jurisdição - não sujeita a uma qualquer relação hicrárquica e criada para funcionar num espírito de cooperação paritária com os Estados-membros -, bem como porá em cheque a eficácia do próprio mecanismo de reenvio prejudicial, e prolongará a duração dos processos $\mathrm{cm}$ caso de reenvio das questöes do TPI para o Tribunal de Justiça ${ }^{54}$. Um tal mecanismo de dupla jurisdição acaba afinal por diminuir a autoridade das decisốes prejudiciais, uma ve\% que as decisões do TPI serão consideradas residuais, provisórias e subordinadas ao Tribunal de Justiça ${ }^{55}$.

\footnotetext{
5. E de salientar aqui que a maior parte dos litígios näo săo entre particulares mas entre as administraçoes públicas dos listados e os particulares que pretendem ver os seus direitos defendidos. Destacam-se os serviços aduaneiros, as administraçöes fiscais, os organismos de intervenção agrícola, as cntidades de gestão conómica, ete.

${ }^{s} \mathrm{~K}$. Lenaerts, «Le Tribunal de première instance des Communates europénenes: regard sur une décennie d'activités ef sur l'apport du double degré d'instance au droit communauaire, Cahiers de droit enopéen, Bruxclas, 2000, p. 323.

${ }_{54}$ A duraça dos processos junto do Tribunal e do TPl é de 20-22 meses num caso e noutro.

A. Johnston, "Judicial Reform and the Treaty of Nice", in Common Marker Law" Revicw, 2001, p. 509 .
} 
Não se trata aqui de questionar as competências do TPI c menos ainda a sua capacidade para apreciar as questões prejudiciais, mas de avaliar a repartição de competências entre o Tribunal de Justiça e o TPI e a possibilidade de uma jurisdição suprena julgar as decisões proferidas em primeira instância.

Perante esta situação algo ambígua, cntendemos que a separação da questão prejudicial entre dois níveis de jurisdição comunitária não se mostra descjável. O facto de o Tribunal de Justiça ser competente para decidir, a lítulo prejudicial, sobre a interpretação do direito comunitário, a validade e interpretação dos actos das instituições da União ${ }^{56}$ é suficiente para reservar ao Tribunal de Justiça a competência exclusiva cm matéria prejudicial e não a partilhar com o TPI.

O Tribunal de Justiça há-de continuar a assumir a responsabilidade principal do processo do reenvio prejudicial. No caso de ter que fazer face a um fluxo importante de questōes prejudiciais, pode, nos termos do artigo 104.", n." 3, do Regulamento do Processo do Tribunal de Justiça, enviar para o juiz nacional uma resposta já fornecida anteriormente pelo próprio Tribunal para que os tribunais nacionais deixem de para ele recorrer.

\subsubsection{Os limites à função prejudicial do TPI}

Esta repartiçăo de competência cm matéria prejudicial não impede que o TPI cnfrente outros limites, para além dos já referidos, para apreciar as questões prejudiciais. Vejamos alguns desses limites.

Em primeiro lugar, as decisões do TPI em matéria prejudicial são susceptíveis de reapreciação pelo Tribunal de Justiça, caso esteja em causa a unidade e a cocrência do dircito comunitário, como acontece no domínio da cooperação policial e judiciária em matéria penal, no respeitante aos vistos, asilo, imigração, e livre circulação das pessoas, conforme dispõem os artigos 35." c 68." do Tratado $\mathrm{CE}$.

Além de se pronunciar sobre as decisôes proferidas pelo TPI cm matéria prejudicial, o Tribunal de Justiça reconsiderará ainda as deliberações do TPI que apreciaram as decisões das câmaras jurisdicionais. O

\footnotetext{
so Artigo Ill-274 da Constituição Europeia.
} 
Tribunal de Justiça deve poder corrigir qualquer interpretação ou aplicação errada do direito comunitário que tenha sido efectuada, quer pelo TPI, quer pelas câmaras jurisdicionais.

Aponta neste sentido o artigo 225.", n." 2 e 3 , do 'Tratado CE que dispóe que "sempre que considere existir um risco grave de lesão da unidade ou da coerência do direito comunitário, o primeiro advogado-geral pode propor ao Tribunal de Justiça a reapreciaçáo da decisão do TPI"57.

Ora, aí se inclui o reexame das decisões do TPI que apreciaram as decisôes das câmaras jurisdicionais. Competindo, por essál via, também ao advogado-geral, no âmbito da sua função jurisdicional, velar pela unidade e coerência do direito comminiário.

Neste caso, o Tribunal de Justiça tem um prazo de um mês a contar da recepção da proposta apresentada pelo primeiro advogado-geral para dizer se a decisăo deve ou não ser reapreciada ${ }^{58}$. Este prazo revela-se, desde logo, demasiado curto, tendo em conta o facto de se tratar de questôes importantes susceptíveis de se repetirem várias vezes.

Em segundo lugar, o exercício da competência prejudicial supõe uma grande independência funcional, a vontade de unificar o dircito, c um espírito de cooperação, o que não se verifica no caso do TPI, pois que este não foi criado para assumir tal tipo de função. O TPI acaba por assumir essa nova função na qualidade de auxiliar do Tribunal de Justiça, não podendo renunciar a cooperar com os órgãos jurisdicionais nacionais, nem deixar de contribuir para a unidade e coerencia do direito comunitários".

Verifica-se, por conseguinte, que a competência do TPI em matéria prejudicial é restrita, provisória e subordinada à do Tribunal de Justiça, o que dificulta a interpretação e aplicação uniforme do direito comunitário. A sua função é restrita precisamente por se limitar às matérias específicas previstas no Estatuto, que iremos em seguida analisar $r^{601}$.

A competência do TPl é provisória uma vez que o Conselho deverá rever as disposições do listatuto três anos após a entrada em vigor do

\footnotetext{
5 Artigo 62." do Estaturo do Tribunal de Justiça.

"Artigo 62." do Estatuto do Tribunal de Justiça.

59 Dámaso Ruiz Jarabo, ob. cir., p. 712.

(n) Artigo 225.", 11."3, do Tratado Cl:
} 
Tratado de Nice ${ }^{61}$. Quanto à sua subordinação ao Tribunal de Justiça, decorre ela de as decisóes adoptadas pelo TPI poderem ser reapreciadas por aquele, mesmo limilado às questões de dircito ${ }^{62}$. Só que năo é viável afirmar a existência de uma jurisdição plena e efectiva e, simultaneamente, subordinar essa jurisdição a uma outra.

A manutenção de duas jurisdições competentes em matéria prejudicial $^{63}$ não garante uma interpretação e aplicação uniforme do direito comunitário, e põe em jogo a própria unidade e coerência do sistema jurídico. Para que este não seja posto em causa, importa seleccionar as questões prejudiciais que devem ser apreciadas pelo Tribunal de Justiça ou pelo TPI, tendo em conta a sua novidade, complexidade ou importância.

Impõe-se identicamente que as jurisdições nacionais sejam mais selectivas nos processos de reenvio prejudicial e se afirmem como juízes ordinários do direito comunitário para que não sejam enviadas sistematicamente questões prejudiciais ao Tribunal de Justiça. Isto supõe que se faça uma selecção das matérias que podem ser apreciadas pelo TPI e pelo Tribunal de Justiça.

Certas matérias específicas são efectivamente da competência prejudicial do TPI.

\subsubsection{As matérias específicas da competência do TPI em matéria prejudicial}

Tal como já foi referido, o artigo 225.", n."3, do Tratado CE atribui ao TPI competência para conhecer as questôes prejudiciais em certas matérias específicas fixadas pelo Esstatulo. Esta disposição permite efectuar uma repartição de competência em matéria prejudicial entre o Tribunal de Justiça c o TPI. A dificuldade é determinar as matérias específicas susceptíveis de serem apreciadas pelo úllimo.

Ora, há várias formas de determinar as matérias específicas.

\footnotetext{
"Artigo 225.", 11."' 2 e 3, do Tratado CH.

6. Artigo 225." n."3, do Tratado CH e artigo 62." do Protocolo relativo ao Estatuto do Tribunal de Justiça.

6. Olivicr Dubos, ob. cit., p. 437.
} 
A primeira consiste na atribuição ao TPI de competências nas matérias técnicas, como a classificação das mercadorias ${ }^{(24}$.

A segunda depende das malérias objecto de recurso directo para o TPI e que passam assim imediatamente para a competência prejudicial do TPI. É o caso, por exemplo, das matérias que relevam do domínio da concorrência. O problema que surge aqui é o de um litígio versar sobre várias matérias em simultâneo e o seu conhecimento c apreciação ter que se repartir entre o Tribunal de Justiça e o TPI. Nesta situaçăo, o TPI deve suspender a instância até que o Tribunal de Justiça se pronuncie ${ }^{6.5}$.

A terceira forma de determinar as matérias especílicas consiste em considerar as matérias que são da competência especílica das câmaras jurisdicionais e estabelecer uma repartição de competências entre o TPI e aquelas.

O Tratado de Nice não referc as matérias que podem ser objecto de transferência, prevendo apenas a possibilidade de alástar a competência do TPI em matéria prejudicial no caso de uma causa exigir uma decisáo de princípio susceptível de afectar a unidade e a cocrência do direito comunitário (artigo 225.", n." 3, do Tratado CE).

Por consequência, admite-se se estabeleça uma certa progressividade na transferência das competências para o TPI. É assim que, por exemplo, o contencioso $\mathrm{cm}$ matéria de propriedade intelectual, a cooperação judiciária em matéria civil e em matéria penal, a coopcração policial, e o direito da concorrência devem passar para a competência do TPI.

Deve notar-se que o contencioso em matéria de propriedade inteleclual, relativo às marcas, desenhos, modelos, patentes e direitos de autor, representa um volume considerável dos litígios que são todos os

\footnotetext{
"á K. I.enaerts, "La réorganisation de l'architecture jurisdictionelle de l'Union Européenne: quel angle d'approche adopter?", in M. Dony e ti. Bribosia (ćd.), L'arenir jurisdictionnel de l'Union turopéenme, Bruxelles, éd. De l'Université de Bruxelles, ILIE, 2002, p. 62

ts. Conforme dispoe o artigo 54 do Fstaturo do Tribunal de Justiça, "quando submetidas ao Tribunal de Justiça e ao TPI várias questoes com o mesno objecto, que suscitem o mesmo problema de interpretaça ou ponham em causa a validade do mesmo acto, o TPI pode, ouvidas as partes, suspender a instância até que seja proferido o acódiăo do Tribunal de Justiça".
} 
anos apresentados no Tribunal de Justiça ${ }^{66}$. Dada a especilicidade do contencioso em matéria de propriedade intelectual, o legislador comunitário previu que tal matéria passasse para a competência de câmaras especializadas criadas para o efeito.

No que diz respeito às matérias referentes ao novo lítulo IV do Tratado CE, elas exigem um tratamento urgente. Todo o contencioso em matéria de asilo, imigração e protecęão dos direitos de nacionais de países terceiros, a cooperaçẫo policial e judiciária $\mathrm{cm}$ matéria penal c a cooperação judiciária em matéria civil deve igualmente passar para a competência prejudicial do TPI e de câmaras jurisdicionais.

Relativamente ao direito da concorrência, as perspectivas de evolução neste domínio são de tal ordem que este ramo carece igualmente de um tratamento especial. O domínio da concorrência representa uma matéria muito sensível para os Estados-membros que obriga um tratamento diferente, apesalr de existir alguma reticência em transferir, por exemplo, o contencioso relativo aos direitos alfandegários.

Prevê-se igualmente a possibilidade de outros litígios virem a desenvolver-se nos próximos tempos. É o caso das intimações para a consulta de documentos das instituições e organismos comunitários pelas pessoas individuais e colectivas, das sançōes do Banco Central Europeu contra as empresas, dos controlos do Tribunal de Contas sobre as pessoas individuais e colectivas beneficiárias de fundos comunitários ou ainda da luta anti-dumping. Todas, matérias específicas que devem ser objecto de um tratamento particular.

Conclui-se do exposto que o domínio de competência do TPI pode recair sobre muitas matérias específicas. A cscolha dessas matérias deve ser feita tendo em conta a unidade c coerência do direito comunitário, o que implica apenas uma transferência daquelas que não afectem, em princípio, essa finalidade, como é o caso da indexação das mercadorias.

Também entendemos que a transferência há-de efectuar-se nos casos em que a jurisdição competente para o eleito não é posta em causa, c existindo uma jurisprudência já estabelecida para que o Tribunal de Justiça possa retirar dela as orientações úteis e necessárias.

66 3000 pedidos de marcas são depositados todos os anos no Instituto de Harmonizaçäo do Mercado Interno. 
Por isso, devem estar perfeitamente identificadas as matérias objecto de transferência, para não surgirem conflitos positivos e negativos de competência entre o Tribunal e o TPI, e para não serem violados os princípios fundamentais de direito comunitário.

\section{AS COMPETÊNCIAS DAS CÂMARAS JURISDICIONAIS}

Para aliviar o 'TPl da sobrecarga de processos que se têm vindo a acumular nestes últimos anos, o art. 225. - A do Tratado CE prevê que o Conselho, deliberando por unanimidade, «pode criar câmaras jurisdicionais encarregadas de conhecer em primeira instância de certas categorias de recursos em matérias específicas. (...) A decisão que crie uma câmara jurisdicional fixará as regras relativas à composiçăo dessa câmara e especificará o âmbito das competências que the forem conferidas». As câmaras têm, destarte, as competências que thes forem atribuídas pelo Conselho.

Prevê-se também que as câmaras jurisdicionais estabeleçam o seu regulamento de processo, de comum acordo com o Tribunal de Justiça e o TPI, para que funcionem em perfeita harmonia com os outros órgãos c de acordo com as regras estabelecidas.

As câmaras jurisdicionais serão compostas por membros escolhidos de entre as pessoas que ofereçam todas as garantias de independência e possuam a capacidade requerida para o exercício de funçoós jurisdicionais, e serão nomeados por unanimidade pelo Conselho ${ }^{67}$.

Essas câmaras jurisdicionais conhecem em primeira instância de certas categorias de recursos em matérias específicas (artigo 225." - A do 'Tratado CE), prevendo-se a possibilidade de as suas decisões serem objecto de recurso para o TPI ou para o Tribunal de Justiça (artigo 225. ", n. "2, do Tratado CE).

As decisões das câmaras admitem recurso para o TPI e excepcionalmente para o Tribunal de Justiça. O TPl é normalmente competente para apreciar as decisões das câmaras em matéria de direito, podendo eventualmente pronunciar-se sobre as questões de facto. Tal como prevê o artigo 225."-A, n. "3, do Tratado CE, "as decisōes das câmaras podem ser objecto de recurso para o Tribunal de Primeira Instância limitado às questões de direito ou, quando tal estiver previsto na decisão que cria a

(3) Artigo 225."-A do Tratado C.F. 
câmara, que incida também sobre as questões de facto".

A apreciação da matéria de lacto é consentida nos litígios em que o exame da matéria seja determinante para obter uma decisăo jurídica. É o que se pode verificar, por exemplo, cm matéria de funcionalismo público.

O artigo 225,"-A do Tratado Cr atribui às câmaras jurisdicionais compctência para conhecer de centas categorias de recursos em matérias específicas, mas năo indica as matérias susceptíveis de serem apreciadas por acuelas.

Em nosso entender, trata-se aqui de todas as matérias que regularmente são apresentadas nos tribunais comunitários e que, em razão da sua especificidade, podem ser melhor apreciadas por uma câmara especializada naquela matéria. As câmaras hão-de ser criadas em função da natureza das causas e da especificidade do contencioso comunitário. Por oulars palavras, essás câmaras jurisdicionais devem obedecer ao critério da especificidade e do domínio de competência da União Europeia.

Con a sua implementação cria-se, na prática, um novo grau de jurisdição para apreciar determinados litígios comunitários e aliviar o Tribunal de Justiça e o TPI. Porém, ao querer-se aliviar as jurisdiçöes comunitárias principais, aumenta-se a estrutura organizacional e o modo de funcionamento de sistema jurisdicional, tornando-se assim mais complexo com uma estrutura composta por três níveis de jurisdiçầ.

Em lugar de proceder a essas alterações na estrutura da jurisdição comunitária, teria sido possível aumentar, no cstado actual da construção jurídica comunitária, o número de membros do TPI e criar secções especializadas no próprio Tribunal para fazer face às especificidades do direito comunitário. Evitar-se-ia assim a criação de um terceiro nível de jurisdição e os efeitos da multiplicação de recursos.

\section{A TR ANSFERÊNCIA DE COMIETÊNCIAS ENTRE, O TRIBUNAL. DE JUSTIÇA E O TPI}

\subsection{A transferência dos recursos directos}

A principal alteração introduzida pelo Tratado de Nice reside na transferência dos recursos directos para o TPI. Essa transferência de competência do Tribunal de Justiça para o TPI e, também, para as câ- 
maras espccializadas altera todo o sistema jurisdicional da União Europcia. Baseia-se ela no artigo 225.", n.' I, do Tratado CE que atribui ao TPI competência para conhecer em primeira instância dos recursos previstos nos artigos 230.", 232.", 235.", 236." c 238." do Tratado CE, com excepção dos atribuídos a uma câmara jurisdicional e dos que o Estatuto reservar ao Tribunal de Justiça. Este deixa assim de exercer o monopólio sobre todos os recursos previstos no Tratado, com excepção das acções por incumprimento (artigos 226." a 228." do 'Tratado CE), dos recursos das decisões do Conselho relativas aos défices orçamentais excessivos (artigo 104. ${ }^{\circ}$, n. ${ }^{\circ}$ II e 12, do Tratado CE), da suspensão dos direitos de um Estado decorrentes da violação grave e persistente, por esse Estado, de algum dos princípios consagrados no artigo 6." do Tratado (artigo 309.", n." 2, do Tratado CE) e da autorização dá constituição de uma cooperação reforçada entre certos Estados-membros (artigo 11.", n." 2, do Tratado CE).

A repartição de competências entre o 'TPI e o Tribunal de Justiça acaba, na verdade, por não ter os efeitos previstos uma vez que o próprio Estatuto do Tribunal afirma no seu artigo 51. "que, "em derrogação da regra enunciada no n." 1 do artigo 225." do Tratado CE (...), são da competência do Tribunal de Justiça as acções propostas e os recursos interpostos pelos Estados-membros, pelas Instituições das Comunidades e pelo Banco Central Europeu". O artigo 51. "do Estatuto derroga assim o artigo 225.", n." I, do Tratado CE na medida em que considera que os recursos apresentados pelos Estados-membros, pelas instituições da União e pelo Banco Central Europeu são da competência do Tribunal de Justiça. São portanto transferidos para o TPI os recursos directos que eram normalmente da competência do Tribunal de Justiça, com excepção daçueles que emanam das instituições principais da Uniăo Europeia e dos Estados-membros.

O lcgislador comminário podia ter optado pelo critério da competência material ou escolhido outro critério, em vez de efectuar uma repartição de competência em função da qualidade do órgão que actua. É sabido que é o Conselho que adopta a maior parte dos actos legislativos $^{68}$, e que, por conseguinte, a maioria dos actos comunitários são apreciados pelo Tribunal de Justiça.

\footnotetext{
th" Antonio Tizzano, "La hiérarchie des notmes communautaires", in Revue du Marché Unique Européen, 1995, n." 3 , pp. 219 esegs.
} 
O objectivo do legislador comunitário consiste em fazer do TPI uma jurisdição de direito comum com competência para julgar uma grande parte dos recursos directos. Para tal, não só foram reforçadas as suas competências, como se tornou necessário criar câmaras jurisdicionais com competencia especializada para apreciar certas categorias de contenciosos, como o da função pública comunitária e da propriedade industrial. A jurisdição comum acaba por ser exercida ao nível do TPI c das câmaras jurisdicionais, cujas decisöes, como já foi referido, são passíveis de recurso para aquele

A descrita transferência dos recursos directos para a competência do TPI não nos parece a solução mais adequada. Poder-se-ia ter adoptado outras vias. A primeira solução, aliás sugerida pela Comissão na Conferencia intergovernamental do ano $2000^{70}$, consistiria na atribuiçăo ao Tl' I de uma competência geral de princípio para apreciar os recursos directos e ao Tribunal de Justiça uma competência para julgar essencialmente as questöes importantes relativas ao funcionamento da Uniăo Luropeia, nomeadamente os recursos interinstitucionais, os recursos contra os actos jurídicos de carácter geral ou especial como os direitos fundamentais, as cooperaçöes reforçadas, o orçamento, a União Económica c Monctária, etc.

Outra solução possível, baseada nas diferentes espécies dos actos objecto de recurso, seria estabelecer acui uma distinçăo entre os de natureza legislativa cos administrativos ou regulamentares adoptados pelos órgãos comunitários, os quais poderiam entar na competência do Tribunal de Justiça ou do TPI. Por exemplo, os actos adoptados pelo Parlamento Europeu e o Conselho de Ministros em regime de co-decisäo, sendo de natureza legislativa, passaniam para a competencia do Tribunal de Justiça.

O problema assenta em que não existe no sistema jurídico comunitário uma classificação e hierarquização entre os diversos actos jurídicos que permita distinguir os actos de natureza legislativa dos ou-

\footnotetext{
(2) Rui Manuel Moura Ramos, "O Tratado de Nice a Reforma do Sistema Jurisdicional

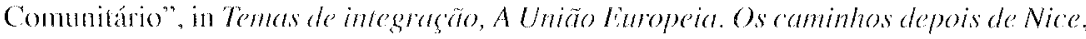
2." semeste de 2001 e $1^{\circ}$ semestre de 2002 , n." 12 e 13. Almedina, p. 93.

70 "A reforma da juristiçăo comunitária". Contribuiçăo complementar a Conferencia intergovernamontal sobre as reformas institucionais, Bruxelas, I de Matço de 2000, Com $(2000)$, 109 linal.
} 
tros. Acontece, muitas vezes, que os aclos legislativos são adoptados conjuntamente com os de natureza administrativa, o que dificulta ainda mais a distinção entre uns e outros.

Por isso, a repartição de competências entre o Tribunal de Justiça c o TPI deve ser perleitamente definida para evitar situações de conflito positivo ou negativo de competência entre os órgãos juriscticionais.

A primeira proposta apresentada visa estabelecer uma justa reparlição de competências de forma a evitar que surja precisamente uma situação de conflito entre as jurisdições. A solução de princípio é a de que o Tribunal de Justiça deve apreciar todos os recursos interinstitucionais, bem como os recursos dos Estados-membros dirigidos contra actos do Conselho ou do Parlamento/Conselho, c o TPI julgar os recursos contra a Comissão e o Banco Central Europeu. Esta repartição de competências resulta essencialmente de o Conselho e o Parlamento poderem adoptar actos de natureza legislativa em co-decisão, enquanto que, em regra, a Comissão adopta actos de natureza administrativa/regulamentar.

O facto de ser atribuída ao Tribunal de Justiça competência para apreciar os actos do Conselho ou do Conselho/Parlamento, independentemente da sua natureza, permite ao Tribunal pronunciar-se sobre actos normativas e não normativos. O mesmo acontece com o TPI em relação aos recursos dos Estados-membros contra os actos da Comissão. Por isso, devem distinguir-se os casos em que o Conselho não actua como "legislador" para atribuir essa competência ao TPI, e os casos em que a Comissão adopta actos normativos para atribuir essa competência ao Tribunal de Justiça ${ }^{71}$.

A partir do momento em que o artigo 225.", n." 1, do Tratado CE diz que "o Estatuto pode prever que o Tribunal de Primeira Instância seja competente para outras categorias de recursos", institui-se, desde logo, uma repartição de competências entre o Tribunal e o TPI baseada na natureza do acto objecto de anulação ou de omissão e na matéria que consta nesse mesmo acto.

Estariam assim reservados ao Tribunal de Justiça os recursos de anulação e de omissão interpostos pelos Estados-membros e dirigidos,

\footnotetext{
7 Antonio Tizzano, "La Cour de justice apress Nice", Revue du Droit de l'Union Européenme, n." 4, 2002, p. 674.
} 
quer contra um acto ou uma abstenção do Parlamento Europeu ou do Conselho ou das duas instituiçóes quando decidem conjuntamente, quer contra um acto ou uma abstenção da Comissão, conforme previsto no artigo 11."-A do Tratado $\mathrm{CE}^{2 / 2}$.

Também caberia ao Tribunal de Justiça apreciar os recursos de anulação ou de omissão interpostos por uma instituição comunitária ou pelo Banco Central Europeu contra um acto ou uma abstençăo do Parlamento Europeu, do Conselho, do Conselho/Parlamento, da Comissão ou de uma instituição da União contra um acto ou uma abstenção do Banco Central Europeu.

Em contrapartida, o TPI scria competente para conhecer das decisões adoptadas pelo Conselho, nos termos do artigo 88. ${ }^{\circ}$, n. ${ }^{\circ} 2$, alínea 2 , dos actos regulamentares do Conselho adoptados em matéria de defesa comercial, conforme prevê o artigo 133.", dos actos de execução do Conselho, scgundo o artigo 202." do Tratado Cl, e dos recursos de anulação e de omissão introduzidos pelas pessoas singulares c colectivas.

\subsection{A necessidade de uma repartição equilibrada}

A repartição de competências entre o Tribunal de Justiça e o TPI deve ser feita de forma equitativa, garantindo um equilíbrio ou uma maior estabilidade no sistema jurisdicional comunitário. Para Rui Manuel Moura Ramos, "o critério de repartição de competências entre o Tribunal de Justiça e o Tribunal de Primeira Instância caracteriza-se, pela sua clareza e simplicidade, uma vez que se ao primeiro está reservado o julgamento dos recursos e acções introduzidos pelos Estados e pelas instituições, para além das questôes prejudiciais, já ao segundo incumbe pronunciar-se em primeira linha sobre os recursos e acções introduzidos pelos particulares"7.3. O TPI é assim competente para apreciar os recursos directos introduzidos pelos particulares, e o Tribunal de

\footnotetext{
72 Artigo 11."-A to Tratado CE: "Qualquer textado-membro que deseje participar ntama cooperação reforçada institúda nos termos do artigo 11." notificará a sua intenção ao Conselho c à Comissão, que apresentará um parecer ao Conselho no prazo de três meses a contar da data de recepção da notificaçăo. No prazo de quatro meses a contar da data de recepeăo da notificação, a Comissăo tomará uma decisão sobre a questäo, bem como sobre eventuais disposições específicas que julgue necessárias".

7.3 Rui Manuel Moura Ramos, ob. cil., p. 88.
} 
Justiça os recursos introduzidos pelas outras entidades.

Só que semelhante repartição de competências cria, por um lado, um desequilíbrio entre os órgãos jurisdicionais, encuanto reforça as competências do Tribunal de Justiça e reduz as do TPI, e, por outro, sobrepõe as competências jurisdicionais das duas instâncias nos processos de reenvio prejudicial, pelo facto de um e outro serem competentes em matéria prejudicial, pondo em causa a unidade coerência do direito comunitário. A actual repartição de competências foi pensada, na verdade, em função da qualidade dos demandantes.

E pode suscilar outras dificuldades processuais, uma vez que o Tribunal de Justiça e o TPI serão eventualmente chamados a apreciar uma mesma questão e proferir decisões contraditórias. Para evitar a pronúncia de decisões contraditórias, o Estatuto do Tribunal de Justiça previu certas medidas processuais, consagradas no artigo $54 .^{\circ}$, n. ${ }^{\prime} 3$ :

a) O TPI pode suspender a instância até que seja proferido o acórdão do Tribunal de Justiça;

b) o Tribunal de Justiça pode suspender a instância até decisão do TPI;

c) o TJ' pode declinar a sua competência a fim que o Tribunal de Justiça decida.

A finalidade destas medidas traduz-se em evitar decisões contraditórias entre o Tribunal de Justiça e o TPI ao apreciar a validade de um acto, isto é, uma decisão da Comissão ou um acto de âmbito geral como o regulamento, ou, excepcionalmente, uma directiva.

Tal regime de suspensão, previsto no artigo 54.", confere ao Tribunal de Justiça a possibilidade de anular actos comunitários ${ }^{74}$, e ao TPI a faculdade de decidir sobre a legalidade dos actos individuais. Esta repartição supõe a existência de Estatutos diferentes para o Tribunal de Justiça e para o TPI, sendo que este último é competente para assegurar a protecção jurídica do particular, e àquele cabe a função de um tribunal constitucional. Apesar da elaboração de medidas preventivas, esta repartição não garante necessariamente uma boa cficácia do sistema jurisdicional comunitário.

Resulta que este dispositivo não é transparente ${ }^{75}$, porque quando

\footnotetext{
${ }^{74}$ Miguel Gorjão-Henriques, Direito Commnitário, Almedina, 2003 , p. 148.
} 
o Tribunal de Justiça decide suspender uma instância até decisão do TPI, ele determina não só os casos que deverão ser julgadas em primeiro lugar, e obriga, por consequência, o TPI a prosseguir os termos do processo ${ }^{76}$. O Tribunal de Justiça acaba por exercer a competencia das compctênciàs.

Foi assim atribuído ao Tribunal de Justiça a função de tribunal constitucional e de juiz supremo e ao TPI a função de tribunal comum para apreciar todos os casos que não são da competência reservada do Tribunal de Justiça.

\section{6. $\Lambda$ NECESSIDADE DE PROSSEGUIR A REFORM DO SISTEMA JURISDICIONAL}

O Tratado de Nice propõe uma reforma importante do sistema jurisdicional comunitário para fazer face às necessidades urgentes que já foram referidas. Reforma que deve ser prosseguida para completar e efectivar algumas das medidas adoptadas e evitar que permaneçam dúvidas e contradições, as quais podem pôr em causa o sistema existente.

Por isso, exige-se uma certa prudênciáa nas alterações legislativas para que não seja comprometida a unidade c cocrência do dircito comunitário, e para que entre o Tribunal de Justiça e o TPI não surjam conflitos positivos e negativos de competência ${ }^{77}$. A função do legislador comunitário não se limita apenas a prevenir qualquer situação de conflito, mas também a năo precipitar as reformas ou adoptar medidas desnecessárias.

O novo sistema jurisdicional comunitário foi pensado para fazer face ao crescente volume de conflitos que, nos últimos anos e com os sucessivos alrgamentos, têm congestionado o Tribunal de Justiça e o TPI. Para o efeito, foram alargadas as competências do TPI, atribuído-se-the a faculdade de conhecer as questões prejudiciais submetidas

\footnotetext{
75 Ulrich Klinke, "Quelques réllexions à propos de la relation entre la Cour de Justice et le Tribunal de première instance des Communautés européennes», Reve des affares curopécnnes, $n^{\circ} 3,2000$, p. 245 e segs.

76 Ulrich Klinke, ob. cit., p. 249.

${ }^{77}$ Dámaso Ruiz Jamabo, ob. cit., p. 722.
} 
pelos tribunais nacionais ${ }^{78}$, algo a que o Tribunal de Justiça se tem sempre oposto por considerar que o processo do reenvio prejudicial é do seu domínio de competência exclusiva. Também, com o alargamento e aprofundamento da União Europeia, foi necessário criar câmaras jurisdicionais com competencias especializadas para conhecer das matérias específicas previstas no Estatuto.

A Constituição Europcia, que foi assinada em 29 de Outubro de 2004, prevê a criação de tribunais especializados, em lugar das câmaras jurisdicionais, dependentes do Tribunal de Grande Instância - actual TPI - e encarregados de conhecer em primcira instância certas categorias de acções em matérias específicas" ${ }^{79}$. Tal como acontecia com as câmaras jurisdicionais, "as decisões dos tribunais especializados podem ser objecto de recurso para o Tribunal de Grande Instância, limitado às questöes de direito ou, quando tal estiver previsto na lei europeia que cria o tribunal especializado, que incida também sobre as questões de facto"sto

O novo sistema transforma o TPI ou Tribunal de Grande Instância numa jurisdição comum competente para apreciar directamente certos recursos e os recursos das câmaras jurisdicionais ou tribunais especializados, limitados às questões de direito ou, quando tal estiver previsto, à matćria de facto. Fica assim aliviado o Tribunal de Justiça que se transforma na jurisdição suprema.

Uma ve que se prevê a criação de tribunais especializados ${ }^{81}$, não ć de excluir a hipótese de virem a ser criados Tribunais de Primeira Instância ou Tribunais de Grande Instância em vários Estados-membros. Estes tribunais teriam uma competência territorial de âmbito regional e destinada a um conjunto de Estados-membros. A criação de tribunais regionais é uma questão que deve ser ponderada pelo legislador comunitário tendo em conta o alargamento da União Europeia e a necessidade de aproximar a justiça comunitária dos cidadãos. Essas jurisdições

\footnotetext{
${ }^{78}$ Artigo 225.", $1{ }^{\circ} 3$, do Tratado Cl:

79) Artigo lll-264, n." I, da Constituiçâo Europeia.

${ }^{80}$ Artigo lll-264, n." 3, da Constituiçăo Europcia.

${ }^{81}$ Retatório do Circulo de discussäo sobre o Tribunal de Justiģa destinado aos membros da Convençäo Europeia sobre o Funaro da tiuropa, de 25 de Marȩo de 2003, doe. CONV $636 / 03$.
} 
regionais estariam obviamente sob a autoridade do Tribunal de Justiça que, actuando como Supremo Tribunal, controlaria a conformidade das decisóes judiciárias com o direito comunitário. Esta solução criaria uma ruptura com o actual sistema baseado na relação privilegiada entre o Tribunal de Justiça, o TPI e os tribunais nacionais.

Somos da opinião de que a regionalização do sistema jurisdicional comunitário é descjável para os cidadãos europeus, que teriam assim uma justiça comunitária mais próxima das suas necessidades, e para o próprio Tribunal de Justiça que beneficiaria de um apoio mais alargado nas várias "circunscrições judiciárias da União Europeia"s?

Teríamos assim um tribunal central no Luxemburgo e tribunais regionais em todo o território da União, criados em função do número e do tipo de processos apresentados junto dos Estados-membros. Caberia aqui ao legislador comunitário definir os casos em que se justifique a criação de tribunais regionais ou de tribunais especializados.

Em matéria de patente comunitária foi decidida a criação pelo Conselho de Ministros, em 3 de Março de 2003, de uma única câmara jurisdicional no l uxemburgo, e não á criação de uma câmara regional. Esta câmara, designada por Tribunal de Patente Comunitário, deve ser implementada até o ano de 2010. Entretanto, os litígios serão julgados pelas jurisdições nacionais que podem sempre utilizar o mecanismo do reenvio prejudicial.

Importa, neste contexto, referir que a regionalização só se mostrará possível se forem criados tribunais especializados em vários Estadosmembros, e preservada a unidade c cocrência do direito comunitário. Hoje, ainda não se verifica essa descentralizaçăo pelo facto das diferentes câmaras jurisdicionais do TPI continuarem reunidas no Luxemburgo. Com a descentralização dessas câmaras tornar-se-á possível concretizar a dita regionalização.

Além disso, com o acréscimo de processos e a especialização do direito comunitário nos diversos domínios de actividade dos Estados-membros, parece-nos irreversivel a descentralização do sistema jurisdicional comunitário, porque são esses tribunais especializados que melhor respondem às necessidades dos cidadãos.

\footnotetext{
82 Georges Vandersanden, «t es système juridictionnel communaulatre après Nice», Ca. hiers de droit européen, Bruxelas, a. 38, n." ${ }^{\text {cis }}[-2,2003$, p. 4.
} 
A criação de tribunais especializados acompanha, na verdade, as novas realidades do direito comunitário, que não pode continuar a ser visto na sua globalidade, mas deve antes ser considerado em função da sua especialidade, uma vez que penetra os diversos domínios da actividade humana.

A nova organização judiciária resultante do Tratado de Nice c confirmada pela Constituição Europeia aproxima-se, na verdade, muito do modelo federat americano, em que o direito da federação é aplicado em cada Estado federado através dos tribunais federais ${ }^{83}$. O modelo da União Europeia mostra-se neste aspecto mais flexível, na medida em que a aplicação do direito comunitário depende da vontade das autoridades nacionais ${ }^{8-1}$.

Só que o modelo comunitário, tal como está configurado, e de que fazem parte quer o Tribunal de Justiça, quer o 'TPI, quer as câmaras jurisdicionais, constitui um sistema particularmente complexo, uma vez que cada uma das jurisdições participa na formação e na exceução do direito comunitário, correndo o risco de pôr cm causa a unidade e coerência do mesmo.

O actual sistema jurisdicional baseia-se no princípio de que o juiz de primeira instância é o juiz dos cidadãos comunitários ${ }^{85}$ e o juiz do Tribunal de Justiça é o das instituições comunitárias e dos Estados, com excepção das questões prejudiciais que podem ser apreciadas por am-

8.3 Carlos Lerreina de Almeida, Imtroduşăo ao Direito Comparado, Almedina, 1998 , p. 129

"4.4 O legislador curopeu renunciou a uma solução federal, da qual caberia recurso para o Tribunal de Justiça das decisôes dos tribunais nacionais contrátias às normas de direito comunitário. Uma tal soluçāo significaria o estabelecimento de uma relaçäo de hierarquia entre os tribunais nacionais co Tribunal de Justiça, e, por conscguinte, a anulação das decisóes dos tribunais nacionais incompativeis com o direito comunitário. Contudo, uma vez que a decisăo prejudicial proferida pelo Tribunal de Justiça é obrigatória para o juiz nacional, este deverá desaplicar o dircito nacional sempre que a decisão for incompativel com o dircito comunitário. Nesta perspectiva, o reenvio prejudicial conduz a um resultado linal pouco diferente dacuele que se verifica numa federação quando o tribunal competente anula o direito estadual contrário ao direito federal.

8.5 Georges Vandersanden, «Le Tribunal de prenière instance des Communautés curopéennes : dix ans d'existence», in Le nouvean modele européen, Paul Magnette e Éric Remacle, Institut d'ètudes Ituropécnnes, Fitora da Universidade de Bruxelas, 2000, p. $106 \mathrm{cosegs}$. 
bas as jurisdições ${ }^{8 h}$. Ora, precisamente esta dualidade pode ameaçar a unidade e coerência do direito comunitário.

No que se refere à repartição de competências entre o Tribunal de Justiça e o TPI, o legislador comunitário decidiu alargar as competências do TPI com vista a descongestionar o Tribunal de Justiça e permitir que este último se concentre nas questöes essenciais para a ordem jurídica comunitária. Este acréscimo de responsabilidades atribuídas ao TPI acaba, na realidade, por ser partilhado entre este c as câmaras jurisdicionais, que passam a actuar nalguns domínios específicos. Esta nova arquitectura jurisdicional, que faz do TPI um tribunal comum competente nalgumas matérias, do Tribunal de Justiça um tribunal supremo, e das câmaras jurisdicionais tribunais especializados de primeira instância, altera todo o sistema inicialmente previsto, tornando-o mais complexo e menos eficaz.

Face ao acréscimo do número de processos, ao desenvolvimento das actividades da União Europeia, e ao alargamento da União Europeia, torna-se cada vez mais importante assegurar a unidade c coerência de todo o sistema. Precisamente neste aspecto, a jurisprudência comunitária tem um papel fundamental a desempenhar como elemento estruturante da ordem jurídica e garante do primado do direito comunitário.

As soluções consagradas no Tratado de Nice e na Constituição Europeia apresentam aspectos positivos, mas também facetas negativas que deverão ser corrigidos numa próxima revisão dos Estatutos do Tribunal de Justiça e do TPI, para năo pôr em perigo a unidade do dircito comunitário.

\section{CONCLUSÃO}

O Tratado de Nice veio afirmar a necessidade de as instituições comunitárias, os Estados-membros e os cidadãos comunitários participarem na elaboração de uma verdadeira reforma do sistema jurisdicional para tentar aproximar os cidadãos do sistema comunitário e garantir os

\footnotetext{
"Georges Vandersanden, «Le systeme juridictionnel ...», ob. cit., p. 7.
} 
seus direitos e interesses fundamentais ${ }^{87}$.

Nesta reforma do sistema jurisdicional, a preocupação essencial do legislador foi a de assegurar, em todos os casos, uma interpretaçäo e aplicação uniforme do direito comunitário, uma proteç̧ão efectiva dos direitos e interesses das pessoas individuais e colectivas e de tornar o sistema jurisdicional mais eficiente face ao acréscimo de processos.

Perante o aumento signilicativo de processos e o congestionamento do Tribunal de Justiça e do TPl, o legislador comunitário reviu a arquitectura jurisdicional para que o Tribunal de Justiça, o TPI c as câmaras jurisdicionais possam dar uma resposta aos diversos requerimentos apresentados.

Sem pôr em causa a vocação do Tribunal de Justiça como órgão supremo do sistema e principal responsável pela unidade e coerência do direito comunitário, foi atribuído ao TPl a função de jurisdiçầo comum de primeira instância, com competencia geral para apreciar recursos directos e questões prejudiciais e prevista a criação de camaras jurisdicionais especializadas nalgumas matérias. As competências dessas câmaras jurisdicionais e do TPI devem estar perleitamente definidas e em plena articulação com a do Tribunal de Justiça para que não se crie uma sobreposição de competências.

Tal organização judiciária transforma o Tribunal de Justiça num tribunal constitucional, o TPl numa jurisdição de primeira ou de segunda instância conforme aprecic ou não as decisões das câmaras jurisdicionais, e as câmaras jurisdicionais num órgão jurisdicional especializado de primeira instância.

É de salientar a adaptação do sistema jurisdicional às novas exigências comunitárias derivadas do alargamento e aprofundamento da União Europeia em vários domínios específicos. Previu-se a criação de câmaras jurisdicionais ou tribunais especializados, conforme prevê a Constituição Europeia, encarregadas de conhecer em primeira instância, e em total independência, certas categorias de recursos. Essas câmaras jurisdicionais destinam-se a aliviar o TPI nas matérias mais específicas do dircito comunitário, mas permanecem sob o controlo do

\footnotetext{
"A. Mattera, «"Civis europacus sum". Ciroyenneté europécnne, droit de circulation ef de séjour, applicabilité directe de l'article 8-A du traté CF», Revue du Marhé Commm et de l'Union Européenne, 1998, pp. 5 e segs.
} 
TPl uma vez que as decisões proferidas pelas câmaras jurisdicionais podem ser objecto de recurso para o TPI ou reapreciadas, excepcionalmente, pelo Tribunal de Justiça, caso exista um risco grave de lesão da unidade ou da coerência do direito comunitário.

Contudo, entre as diversas instâncias jurisdicionais criaram-se relações complexas que não são favoráveis a uma boa administração da justiça. Ocorre notar, por exemplo, uma sobreposiçăo de competências entre o Tribunal de Justiça e o TPI, resultante da transferência de competências do primeiro para o segundo, em matéria de recnvio prejudicial. As duas instâncias passam a ter competência para interpretar c aplicar o direito comunitário.

Resulta do exposto que o legislador se limitou a lançar as linhas gerais do novo quadro jurisdicional comunitário, deixando por resolver muitas das questöes relativas às competências do Tribunal de Justiça, do TPl c das câmaras jurisdicionais, que parecem estar a proporcionar uma possível descentralização da justiça comunitária.

A Constituição Europeia confirma as alterações introduzidas pelo Tratado de Nice, bem como a necessidade de aperfeiçoar o sistema jurisdicional comunitário, e de melhor definir as competencias das novas instâncias jurisdicionais e as suas relações com os Estados-membros.

Resta saber, porém, se a Constituição europeia vai mesmo entrar em vigor, após o veto da França e da Holanda, ou se vai sofrer alguma alteração para que estes Estados a possam vir ainda a ratificar. 